\title{
Differenz
}

Revista internacional de estudios heideggerianos y sus derivas contemporáneas

AÑO 3 NÚMERO 2: JULIO DE 2016. e-ISSN: 2386-4877 - DOI: 10.12795/DIFFERENZ.2016.I02.19

[pp. 279-281]

\section{SAVIANI, C. (2004): El Oriente de Heidegger. Barcelona: Herder, 173 pp. Traducción de Raquel Bouso García.}

\section{Luís Roca Jusmet \\ Catedrático de Filosofía ES. Barcelona}

No hace pocos años hubo en Francia una interesante discusión entre dos filósofos europeos (y sinólogos muy potentes. Uno era el francés François Jullien y el otro el belga Jean-François Billeter. El primero defendía que la filosofía es una invención iniciada en Grecia , continuada en Europa, que la sabiduría china rechazó para seguir otro camino del pensar. Jullien quería ir hacia este Otro de la filosofía que era China para repensar nuestro propio pensar desde lo más radicalmente diferente. Billeter, por el contrario, defendía que la filosofía es una experiencia universal en la que podemos situar tanto a Platón como Chuang-Tzui. Heidegger se situaría, sin duda,en la posición de Jullien, ya que para él la filosofía es el camino del pensar que no puede aparecer en otra lengua que el griego. Lo las sabidurías extremo-orientales nos pueden enseñar, entonces, es algo que está fuera de nuestro horizonte filosófico. La diferencia con Jullien es que Heidegger no conoce el chino ni el japonés, por lo que no puede acceder directamente a las fuentes. Aunque sí puede dialogar con chinos y japoneses que se sitúan en una perspectiva radicalmente diferente de la que podemos aprender algo. La limitación de Heidegger es la misma que tenía Schopenhauer, otro filósofo alemán que fue el iniciador, un siglo antes, de la fascinante por Oriente. Aunque antes que por China, Schopenhauer se interesara por la "India" que no le interesa en absoluto. Comparten los dos la crítica a la modernidad y la búsqueda en este Otro de una sabiduría perdida. La ventaja de Heidegger sobre 
Schopenhauer será, de todas maneras, que el acceso a este saber no será únicamente a partir de los textos sino del diálogo con algunos de sus representantes más significativos.

Carlo Saviani nos ofrece en este texto una excelente introducción sobre el interés, las referencias y los encuentros de Martin Heidegger con el taoísmo chino y el budismo zen japonés. Es un estudio tan claro como preciso, con una excelente introducción, dos capítulos dedicados a las confrontaciones respectivas con el taoísmo y el budismo zen y una serie de apéndices de primera mano, escritos o por Heidegger o con chinos y japoneses que conectaron con él. Me llama la atención una analogía que me resulta muy sugerente. Jacques Lacan y Michel Foucault, son dos de los grandes pensadores (ambos franceses) de la segunda mitad del siglo XX. Los dos reconocen una gran influencia de Heidegger. Cada uno de ellos podríamos decir que recoge una de las dos experiencias que Heidegger lleva a cabo con el taoísmo y el budismo zen. Lacan se pondrá en contacto con un chino con el que mantiene mucha afinidad, François Cheng, para aproximarse al taoísmo e incluso hacer una traducción conjunta del Tao te King. Justo un tiempo antes, como nos explica el libro que nos ocupa, Heidegger dialoga e intenta traducir el mismo tao te King con Paul Shih-Yi Hsiao, un estudiante chino que asistió a los cursos de Heidegger en Friburgo y que mantuvo con él una larga y fructífera amistad. Foucault, por su parte, estuvo muy interesado en el budismo zen. El libro de Eugen Herrigen "El zen del tiro con arco" era uno de sus libros de cabecera y el año 1972 viajó al Japón y estuvo unos días aprendiendo meditación en un templo zen.

En todo caso, lo que sí merece un estudio en profundidad, es la relación de la filosofía de Heidegger con la filosofía de la Escuela de Kioto y con el budismo zen. Hay múltiples referencias y en un sentido bilateral. Trata el libro de los primeros encuentros, de las conversaciones con Shuzo Kuki, con D.T. Suzuki, con Tomio Tezuka, entre otros. Igualmente es significativo la enorme recepción que tuvo la traducción japonesa de ¿Qué es la metafísica? Casi como si en el Japón hubieran captado mejor el sentido de la Nada heideggeriana. Este conjunto de documentos acaba con la transcripción de la conferencia que Koichi Tsujimara pronunció en honor a Heidegger y en su presencia y la respuesta del filósofo alemán. Por supuesto que todo este recorrido no puede acabar sin una referencia a la famosa conversación con T. Tezuka, que Heidegger incluye en su Camino al habla, reescribiéndolo con el título De un diálogo acerca del habla entre un japonés y un inquiridor. Hay todo un trabajo abierto en este sentido. El mismo Saviani reconoce que este es el papel que quiere representar, el de abrir una nueva puerta para entender la filosofía de Heidegger, no desde el trabajo de la propia tradición filosófica sino desde este diálogo con el budismo zen y sobre todo la Escuela de Kioto. Saviani nos ofrece una rigurosa y extensa bibliografía para hacerlo. El libro se escribió en 1998 y el autor hace 
una presentación para la edición española y actualiza la bibliografía. La traductora, Raquel Bouso García, realiza una traducción exquisita del italiano y no hay que olvidar que es una de las mejores conocedoras en nuestro país de lo que podríamos Ilamar la filosofía del budismo zen. 